\title{
DOPPLER STUDY OF SPLENIC ARTERY AND RENAL ARTERY RESISTIVE INDEX AS A PREDICTIVE OF ESOPHAGEAL VARICES AND ITS BLEEDING RISK IN EGYPTIAN CIRRHOTIC PATIENTS
}

\author{
By
Shaban Salah Al-Azhary*, Samy Zaky*, Abdullah Hussein Ahmed**, and Mahmoud Hagag Abd El Fadeel* \\ * Tropical Medicine Department - Al-Azhar Faculty of Medicine, ** Radiology \\ Department - Al-Azhar Faculty of Medicine (Girls)
}

\begin{abstract}
Background: Esophageal varices (EV), a major complication of liver cirrhosis, can lead to life threatening through gastrointestinal (GI) bleeding. Early detection of EV and prediction of its bleeding risk is important.

Objectives: Evaluate the resistive index (RI) of the renal artery (RA) and splenic artery by Doppler in various stages of liver cirrhosis, and their values for detection of EV and its bleeding.

Patients and Methods: This study included Sixty six patients with confirmed diagnosis of LC, twenty two patients with esophageal varices and having history of variceal bleeding episodes, twenty four patients with esophageal varices and having no variceal bleeding episodes history, and twenty patients without esophageal varices. All patients were subjected to history taking, clinical examination, laboratory investigations, calculation of some important non-invasive indices (CHILD, FIB 4, and APRI), abdominal ultrasonography, renal and splenic artery Doppler, and Upper GI endoscopy.

Results: RA RI served as predictors of the presence as well as bleeding risk of esophageal varices, and this prediction capability further empowered when both LRA RI and RRA RI were incorporated in a prediction equation, predicting the presence of esophageal varices with $95.7 \%$, sensitivity and $50 \%$ specificity at a cut off value of 0.715 . Also, LRA RI revealed a sensitivity of $81.8 \%$, and a specificity of $50 \%$ at the cut off value of 0.725 for prediction of esophageal varices bleeding. The splenic artery resistive index revealed a sensitivity of $69.6 \%$, and a specificity of $90.1 \%$ for prediction of esophageal varices in a cut off value of 0.715 and a sensitivity of $68.2 \%$, and a specificity of $70.5 \%$ for prediction of esophageal varices bleeding in a cut off value of 0.725 .
\end{abstract}

Conclusion: Resistive index of the renal artery may help in predictions of esophageal varices and its bleeding risk, LRA RI was more sensitive for prediction of esophageal varices bleeding. In contrast, the splenic artery was less sensitive for prediction of esophageal varices and its bleeding risk.

Key words: Resistive Index (RI), Doppler studies, Liver cirrhosis (LC), Esophageal varices (EV). 


\section{INTRODUCTION}

Bleeding from ruptured esophageal varices is the main complication of portal hypertension and is a major cause of death in patients with cirrhosis (Augustin et al., 2010), it is estimated that one-third of patients with cirrhosis and esophageal varices will bleed from those varices during their lifetime. (Mishra, 2016). Therefore, some form of intervention to prevent the first bleed and thereby reduce mortality seems logical. So, for patients with compensated cirrhosis, the diagnosis and grading of clinically significant portal hypertension enable the prediction of prognosis (Kim et al., 2015). Thus, the precise grading of $\mathrm{PH}$ is essential for appropriate prophylactic treatment and follow- up of patients with cirrhosis (Baik, 2010). The current consensus is that all cirrhotic patients should be endoscopically screened for varices at the time of diagnosis (Kraja et al., 2017). Unfortunately, sedation of cirrhotic patients to perform upper endoscopy may be hazardous, and diagnostic upper endoscopy may contribute to bacterial infections due to disruption of the normal barriers (Yosry et al., 2009). In order to reduce the increasing burden placed on endoscopy units, considerable efforts have been made to identify hemodynamic indicators of the risk for variceal bleeding, noninvasively, by Doppler ultrasound (Uppalapati and Lokesh, 2018), Although noninvasive US appears to be reliable surrogate for HVPG for identifying $\mathrm{PH}$, the correlation between US and $\mathrm{PH}$ remains poorly defined (Kim et al., 2015). (Byun and Kim 2007) studied 33 alcoholic cirrhotic patients and found that a high resistive index of the splenic artery and renal artery will be useful in predicting
EV bleeding in patients with alcoholic cirrhosis.

\section{PATIENTS AND METHODS}

This study was conducted at the Tropical Medicine Department in cooperation with Radiology Department, Faculty of Medicine, Al Azhar University hospitals from April 2017 to June 2018. The study was approved by the hospital ethics committee and informed consents were obtained from all patients shared in the study. Sixty six patients with liver cirrhosis that were classified according to the result of the upper GIT endoscopy and according to esophageal variceal bleeding episodes into:

- Group (I): Patients with esophageal varices having variceal bleeding episodes (bleeder group) $(\mathrm{N}=22)$.

- Group (II): Patients with esophageal varices with no variceal bleeding episodes (non-bleeder group) $\mathrm{N}=24$ ).

- Group (III): Patients with no esophageal varices on upper GIT endoscopy $(\mathrm{N}=20)$.

Patients with liver cirrhosis were diagnosed by clinical, laboratory and Ultrasonography methods. APRI (AST to Platelet Ratio Index) (Jain et al., 2015). Patients having sonographic evidence of hepatic focal lesion(s), having either partial or complete portal vein thrombosis, splenic or hepatic vein thrombosis (BuddChiari syndrome), evidence of lower esophageal masses, Splenectomy and any disease other than liver cirrhosis that may affect RI of the renal artery such as acute or chronic kidney disease were excluded from this study. All patients provided informed written consent. 
All patients were subjected to the following:

1) History taking.

2) Clinical examination.

3) Laboratory evaluation.

4) Child-Pugh score classification.

5) Abdominal Ultrasound and Doppler studies: using: Philips Affiniti 70G Machine Convex Probe Frequency: 3.5-5 MHZ. All patients were subjected to a single viewer operator; it evaluated liver and spleen size, the presence of cirrhosis, periportal fibrosis, ascites, or focal lesions and Portal vein diameter.

6) Doppler study of the splenic artery: The transducer was positioned below the left intercostal margin and/or in the left intercostal spaces. Color Doppler allowed the identification of the main branches of the splenic artery. The sample volume of the blood flow velocity wave form was recorded. Peak systolic and end diastolic were determined.

The resistance index (RI) was calculated according to the formulas: RI (peak systolic - end diastolic velocity) peak systolic velocity each result was the mean of at least three measurements (Viazzi et al., 2014).

7) Doppler study of the renal artery: The following regression equation was derived for predicting the presence of esophageal varices. Predictive model equation $=2.91$ RT RA RI+3.25 LT RA RI - 3.79

Which means that for a given patient if the value is $>0.715$, the patient should be investigated (upper endoscopy screening) for large possibility of having esophageal varices.

8) Upper GIT endoscopy using a flexible video gastroscope (Olympus Medical Systems, Japan) and (Pentax Medical Systems, Japan).

A) Esophageal varices: These were graded according to Thakeb et al. (1988) which was based on the modification of the classification of Dagradi et al. (1966)

B) Gastric varices were graded according to the classification of Sarin et al. (1992).

C) Portal hypertensive gastropathy (PHG) was classified according to Primignani et al. (2000).

Statistical testing was performed using IBM SPSS statistics software (version 23). The reported results significance level was set to $\mathrm{p}<0.05$. Data were presented (in tables) either as mean \pm standard deviation and range or the number of cases (percentage of the total count of the respective group) [n (\%)] in case of continuous and categorical variables respectively. ANOVA with Post Hoc (Tukey) test was used for comparing means, and the Chi square test - with Yates correction as necessary - or Fisher's exact test was used for comparing proportions. Multivariate analysis was done to test relation between $\mathrm{EV}$ as dependent variables and other factors using step-wise regression test. A receiving-operating characteristic (ROC) curve was constructed using the level of RR RI and splenic artery RI (0.715) as cut-off points of prediction of EV and using the level of RR RI and splenic artery RI (0.725) as cut-off points of prediction 
of EV bleeding risk. Sensitivity, specificity, positive predictive value
(PPV), negative predictive value (NPV), and test accuracy were calculated.

\section{RESULTS}

Sixty-six cirrhotic patients were included in the study at the Tropical Medicine Department, cooperation with Radiology Department, Faculty of Medicine, Al Azhar University Hospitals from April 2017 to June 2018. Mean age was $53.9 \pm 7.4,29$ males, 37 females. Demographics, baseline clinical, laboratory characteristics and ultra sono graphic findings between the three groups showed no significant difference except with s. albumin, platelet count, splenic diameter $(\mathrm{mm})$, portal vein diameter $(\mathrm{mm})$ and ascites at table (1) which showed significant difference this significance between group 2 (Non bleeder) and group 3 (Non OV), also there are significance between group 1 (bleeder) and group 2 (Non bleeder) in albumin and portal vein diameter.

Table (1): Univariate analysis of demographics laboratory characteristics, scores and ultrasonographic findings among the studied groups

\begin{tabular}{|c|c|c|c|c|c|}
\hline \multicolumn{2}{|l|}{ Variables } & $\begin{array}{l}\text { Group 1 } \\
\text { EV Bleeder } \\
\text { No.22 }(33 \%)\end{array}$ & $\begin{array}{l}\text { Group } 2 \\
\text { EV Non-Bleeder } \\
\text { No. } 24(37 \%)\end{array}$ & $\begin{array}{l}\text { Group } 3 \\
\text { Non-EV } \\
\text { No. } 20(30 \%)\end{array}$ & P value \\
\hline \multirow[t]{2}{*}{\begin{tabular}{|l} 
Age (years) \\
\end{tabular}} & Mean \pm SD & $55 \pm 7.7$ & $54.7 \pm 7.3$ & $51.7 \pm 7.3$ & \multirow[b]{2}{*}{0.31} \\
\hline & Range & $43-66$ & $37-67$ & $39-64$ & \\
\hline Male, n (\%) & & $12(55 \%)$ & $8(33 \%)$ & $9(45 \%)$ & \\
\hline Female, n (\%) & & $10(45 \%)$ & $16(67 \%)$ & $11(55 \%)$ & 0.34 \\
\hline \multirow{2}{*}{$\begin{array}{l}\text { Albumin } \\
(\mathrm{g} / \mathrm{dL})\end{array}$} & Mean \pm SD & $3.1 \pm 0.3^{*}$ & $2.7 \pm 0.5 * \#$ & $3 \pm 0.4 \#$ & \multirow[t]{2}{*}{$0.02 *$} \\
\hline & Range & $2.4-3.6$ & $1.7-3.8$ & $2.3-3.4$ & \\
\hline \multirow{2}{*}{$\begin{array}{l}\text { Platelets } \\
\left(10^{3} / \mathrm{mm}^{3}\right)\end{array}$} & Mean \pm SD & $100.5 \pm 31$ & $86.3 \pm 37.2 *$ & $116.9 \pm 30.9^{*}$ & \multirow[t]{2}{*}{$0.014 *$} \\
\hline & Range & $48-167$ & 18-146 & 36-159 & \\
\hline \multirow{2}{*}{\begin{tabular}{|l|} 
Splenic \\
Diameter $(\mathbf{m m})$ \\
\end{tabular}} & Mean \pm SD & $15.8 \pm 1.5$ & $16.2 \pm 1.4^{*}$ & $14.8 \pm 1.2 *$ & \multirow[t]{2}{*}{$0.005^{*}$} \\
\hline & Range & $13-18.5$ & $13.5-18.3$ & $13-17.3$ & \\
\hline \multirow{2}{*}{$\begin{array}{l}\text { Portal Vein } \\
\text { Diameter }(\mathrm{mm})\end{array}$} & Mean \pm SD & $14.8 \pm 1.1^{*}$ & $14.7 \pm 1.4 \#$ & $13.7 \pm 0.7 * \#$ & \multirow[t]{2}{*}{$0.004 *$} \\
\hline & Range & $11.3-16.3$ & $10-16.2$ & $12-15.3$ & \\
\hline Ascites & & $7(31.8)$ & $15(62.5 \%)^{*}$ & $5(25 \%)^{*}$ & $0.024 *$ \\
\hline \multirow[t]{2}{*}{ APRI } & Mean \pm SD & $1.49 \pm 0.76$ & $1.96 \pm 1.42$ & $1.62 \pm 0.94$ & \multirow[t]{2}{*}{0.33} \\
\hline & Range & $1-4.32$ & $1.02-6.22$ & $1.02-5$ & \\
\hline \multirow[t]{2}{*}{ FIB 4} & Mean \pm SD & $4.8 \pm 2.5$ & $6.4 \pm 5.4$ & $4.1 \pm 1.8$ & \multirow[t]{2}{*}{0.11} \\
\hline & Range & $2.16-14.28$ & $2.43-25.54$ & $1.7-10.25$ & \\
\hline \multirow[t]{2}{*}{\begin{tabular}{|l|} 
Child Pugh \\
\end{tabular}} & Mean \pm SD & $7.2 \pm 1.5$ & $7.96 \pm 1.9$ & $7.1 \pm 1.2$ & \multirow[t]{2}{*}{0.14} \\
\hline & Range & $5-10$ & $5-12$ & $6-10$ & \\
\hline
\end{tabular}

APRI: AST to Platelet Ratio Index.

FIB4: Fibrosis-4 score. 
Data were presented as number of cases (percentage of the total count of the respective group) [n (\%)] Data were presented as mean \pm standard deviation (mean $\pm \mathrm{SD})$.
- Data were calculated by one-way ANOVA in case of continuous variables, or chi square for categorical variables

* \# significance between groups.

Also, Doppler finding between 3 groups showed significant difference between the three groups as regards RARI (RRA, LRA) and splenic artery RI (Table 2)

Table (2): Doppler findings of study patients among the studied groups

\begin{tabular}{|c|c|c|c|c|c|}
\hline \multicolumn{2}{|l|}{ Indices } & \begin{tabular}{|l} 
Group 1 \\
No.22 (33\%)
\end{tabular} & $\begin{array}{l}\text { Group } 2 \\
\text { No.2 }(37 \%)\end{array}$ & $\begin{array}{l}\text { Group } 3 \\
\text { No. } 20(30 \%)\end{array}$ & P value \\
\hline \multirow{2}{*}{$\begin{array}{l}\text { Rt Renal } \\
\text { artery RI }\end{array}$} & Mean \pm SD & $0.75 \pm 0.047 *$ & $0.73 \pm 0.047 \#$ & $0.68 \pm 0.032 * \#$ & \multirow[t]{2}{*}{0.0001} \\
\hline & Range & $0.67-0.83$ & $0.65-0.87$ & $0.64-0.77$ & \\
\hline \multirow{2}{*}{$\begin{array}{l}\text { Lt Renal } \\
\text { artery RI }\end{array}$} & Mean \pm SD & $0.76 \pm 0.05^{*}$ & $0.74 \pm 0.05 \#$ & $0.69 \pm 0.031$ *\# & \multirow[t]{2}{*}{$<0.0001$} \\
\hline & Range & $0.67-0.89$ & $0.67-0.85$ & $0.64-0.75$ & \\
\hline \multirow{2}{*}{$\begin{array}{l}\text { Splenic } \\
\text { artery RI }\end{array}$} & Mean \pm SD & $0.75 \pm 0.05^{*}$ & $0.72 \pm 0.053 \#$ & $0.68 \pm 0.032 * \#$ & \multirow[t]{2}{*}{$<0.0001$} \\
\hline & Range & $0.67-0.89$ & $0.64-0.84$ & $0.63-0.76$ & \\
\hline
\end{tabular}

- Calculated by one-way ANOVA in case of continuous variables.

* ,\# significant between groups

To develop a model for detection of esophageal varices group 1 (esophageal varices bleeder group) and group 2 (esophageal varices non-bleeder group) were analyzed as a single group vs. group
3 no esophageal varices group showed significant difference in splenic size $(\mathrm{cm})$ and portal vein diameter $(\mathrm{mm})$ between two groups, and no significant difference in ascites and child score (Table 3 ).

Table (3): Baseline ultrasonographic findings differentiating group I+II from group III

\begin{tabular}{|c|c|c|c|c|}
\hline Variables & Groups & \begin{tabular}{|l|} 
Group 1+ Group 2 \\
EV No. 46 $(69.7 \%)$ \\
\end{tabular} & \begin{tabular}{|l|} 
Group 3 \\
Non EV No. $20(30.3 \%)$ \\
\end{tabular} & $P$ value \\
\hline \multirow{2}{*}{$\begin{array}{l}\text { Splenic size } \\
\text { (cm) }\end{array}$} & Mean \pm SD & $16.03 \pm 1.5$ & $14.80 \pm 1.25$ & \multirow[t]{2}{*}{0.002} \\
\hline & Range & $13-18.5$ & $13-17.3$ & \\
\hline \multirow{2}{*}{$\begin{array}{l}\text { Port vein } \\
\text { diameter PVD } \\
(\mathbf{m m})\end{array}$} & Mean \pm SD & $14.8 \pm 1.28$ & $13.7 \pm 0.68$ & \multirow[t]{2}{*}{0.001} \\
\hline & Range & $10-16.3$ & $12-15.3$ & \\
\hline \multicolumn{4}{|l|}{ Ascites } & \multirow[t]{4}{*}{0.379} \\
\hline Mild, n (\%) & & $8(17.4 \%)$ & $1(5 \%)$ & \\
\hline $\begin{array}{l}\text { Moderate, } n \\
(\%)\end{array}$ & & $11(24 \%)$ & $2(10 \%)$ & \\
\hline Marked, n (\%) & & $3(6.5 \%)$ & $2(10 \%)$ & \\
\hline \multirow[t]{2}{*}{ Child score } & Mean \pm SD & $7.6 \pm 1.8$ & $7.2 \pm 1.2$ & \multirow[t]{2}{*}{0.31} \\
\hline & Range & $5-12$ & $6-10$ & \\
\hline
\end{tabular}

- calculated by student t-test in case of continuous variables, or qui-square for categorical variables.

* significant value. 
Another table for Doppler finding between group I + II (OV patients) and group III (Non OV patients) show significant difference in RARI (RRA, LRA) and splenic artery RI table (4).

Table (4): Doppler findings of study patients differentiating group I+II from group III

\begin{tabular}{|c|c|c|c|c|}
\hline \multicolumn{2}{|c|}{ Indices Groups } & $\begin{array}{c}\text { Group 1+Group } 2 \\
\text { No. } 46(69.7 \%)\end{array}$ & $\begin{array}{c}\text { Group 3 } \\
\text { No. } 20(30.3 \%)\end{array}$ & $P$ value \\
\hline \multirow{2}{*}{$\begin{array}{l}\text { Rt Renal } \\
\text { artery RI }\end{array}$} & Mean \pm SD & $0.74 \pm 0.049$ & $0.68 \pm 0.033$ & \multirow[t]{2}{*}{$<0.0001$} \\
\hline & Range & $0.65-0.87$ & $0.63-0.77$ & \\
\hline \multirow{2}{*}{$\begin{array}{l}\text { Lt Renal } \\
\text { artery RI }\end{array}$} & Mean \pm SD & $0.75 \pm 0.049$ & $0.69 \pm 0.031$ & \multirow[t]{2}{*}{$<0.0001$} \\
\hline & Range & $0.67-0.89$ & $0.64-0.75$ & \\
\hline \multirow{2}{*}{$\begin{array}{l}\text { Splenic } \\
\text { artery RI }\end{array}$} & Mean \pm SD & $0.74 \pm 0.054$ & $0.68 \pm 0.032$ & \multirow[t]{2}{*}{$<0.0001$} \\
\hline & Range & $0.64-0.89$ & $0.63-0.76$ & \\
\hline
\end{tabular}

- Calculated by student t-test in case of continuous variables.

All variables that were found to be significant in the univariate analysis were included as candidate variables in forward logistic regression analysis to identify independent predictors for the presence of esophageal varices. In this analysis, only two predictors, namely RRA RI and LRA RI were found to have independent predictive values for the presence of esophageal varices. ROC curve analysis of the predictive model equation revealed that a cut off value of (0.397) has a sensitivity of $95.7 \%$, and a specificity of $50 \%$ for prediction of esophageal varices. Which means that for a given patient if the value is $>0.397$, the patient should be investigated (upper endoscopy screening) for large possibility of having esophageal varices (Figure 1).

\section{Figure (1): ROC curve of the prediction model for esophageal varices detection}

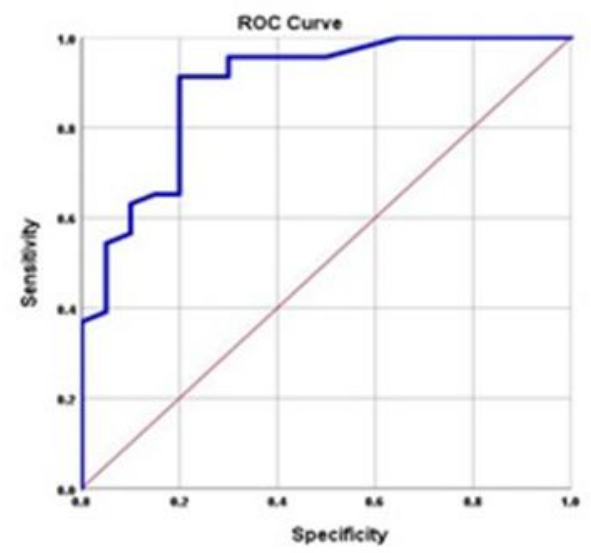

ROC curve analysis of the LT RA RI revealed that a cut off value of (0.715) has a sensitivity of $80.4 \%$, and a specificity of
$75.0 \%$ for prediction of esophageal varices (Figure 2). 
Figure (2): ROC curve of the LRA RI for esophageal varices detection

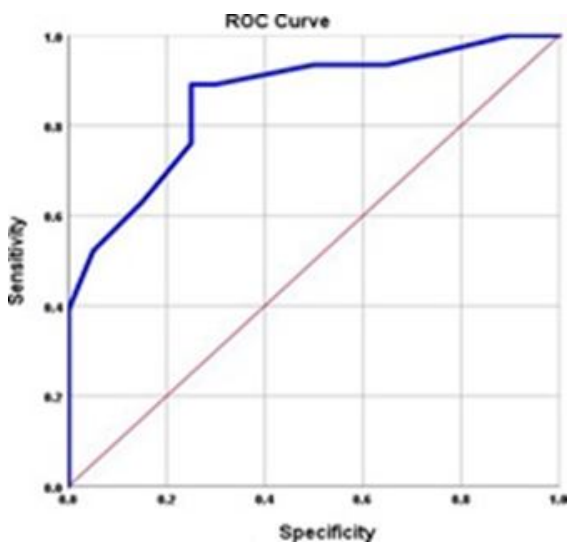

Also, ROC curve analysis of the RT specificity of $85.0 \%$ for prediction of RA RI revealed that a cut off value of esophageal varices (Figure 3). (0.715) has a sensitivity of $76.1 \%$, and a

Figure (3): ROC curve of the RRA RI for esophageal varices detection

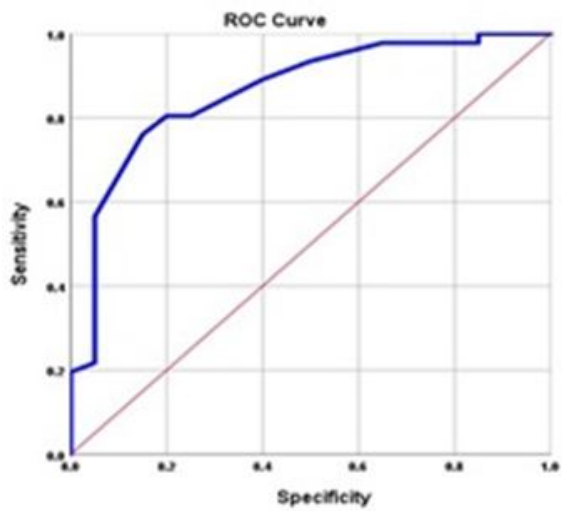

ROC curve analysis of the splenic artery revealed that a cut off value of (0.715) has a sensitivity of $69.6 \%$, and a specificity of $90.1 \%$ for prediction of esophageal varices (Figure 4).

Figure (4): ROC curve of the splenic artery RI for esophageal varices detection

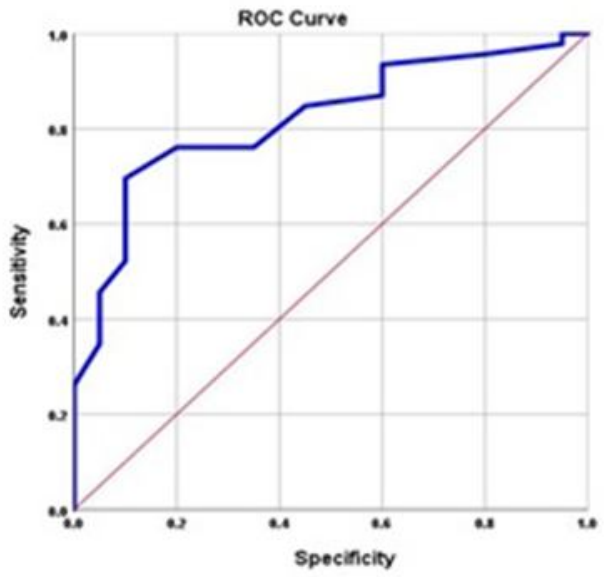


Another model was developed for the prediction of the presence of bleeder esophageal varices. So, why group 2 and group 3 were analyzed as a single group vs. group 1 to develop a model for detection of esophageal varices bleeding (Table 5).

Table (5): Doppler findings of study patients differentiating group I from group II + III

\begin{tabular}{|c|c|c|c|c|}
\hline \multicolumn{2}{|c|}{ Groups } & \begin{tabular}{|l} 
Group 1 \\
bleeding \\
No. $22(33.3 \%)$ \\
\end{tabular} & \begin{tabular}{|l|} 
Group 2+Group 3 \\
Non-bleeding \\
No. $44(66.7 \%)$ \\
\end{tabular} & P value \\
\hline \multirow{2}{*}{$\begin{array}{l}\text { Rt Renal } \\
\text { artery RI }\end{array}$} & $\underline{\text { Mean } \pm \text { SD }}$ & $0.75 \pm 0.047$ & $0.71 \pm 0.048$ & \multirow[t]{2}{*}{0.001} \\
\hline & Range & $0.67-0.83$ & $0.63-0.87$ & \\
\hline \multirow{2}{*}{$\begin{array}{l}\text { Lt Renal } \\
\text { artery RI }\end{array}$} & Mean \pm SD & $0.76 \pm 0.051$ & $0.72 \pm 0.047$ & \multirow[t]{2}{*}{0.001} \\
\hline & Range & $0.67-0.89$ & $0.64-0.85$ & \\
\hline \multicolumn{2}{|c|}{ Splenic arteryMean \pm SD } & $0.75 \pm 0.053$ & $0.71 \pm 0.049$ & \multirow[t]{2}{*}{0.001} \\
\hline RI & Range & $0.67-0.89$ & $0.63-0.84$ & \\
\hline
\end{tabular}

- Calculated by student t-test in case of continuous variables.

All variables that were found to be significant in the univariate analysis were included as candidate variables in stepwise logistic regression analysis to identify independent predictors for the presence of bleeder esophageal varices. In this analysis, LT RA RI was found to have independent predictive value for the presence of bleeder esophageal varices.
ROC curve analysis of LT RA RI revealed that a cut off value of $(0.725)$ has a sensitivity of $81.8 \%$, and a specificity of $50 \%$ for prediction of esophageal varices bleeding, which means that for a given patient if the value is $>0.725$, the patient should be investigated (upper endoscopy) for large possibility of having bleeder esophageal varices (Figure 5).

\section{Figure (5): ROC curve of the LRA RI for esophageal varices bleeding}

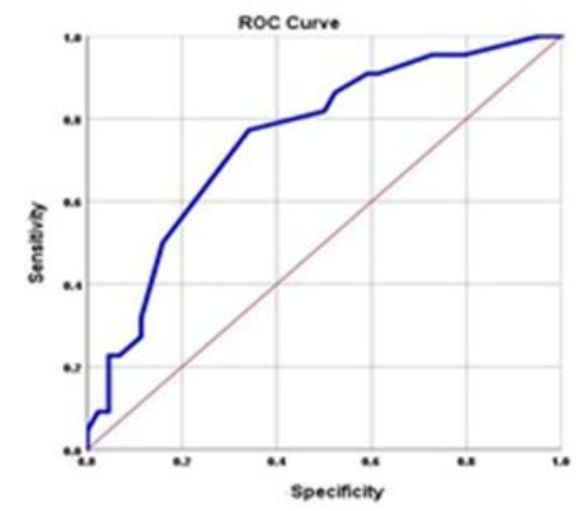

ROC curve analysis of RT RA RI revealed that a cut off value of $(0.725)$ has a sensitivity of $68.2 \%$, and a specificity of $72.7 \%$ for prediction of esophageal varices bleeding, which means that for a given patient if the value is $>0.725$, the patient should be investigated for large possibility of having bleeding esophageal varices (Figure 6). 
Figure (6): ROC curve of the RRA RI for esophageal varices bleeding

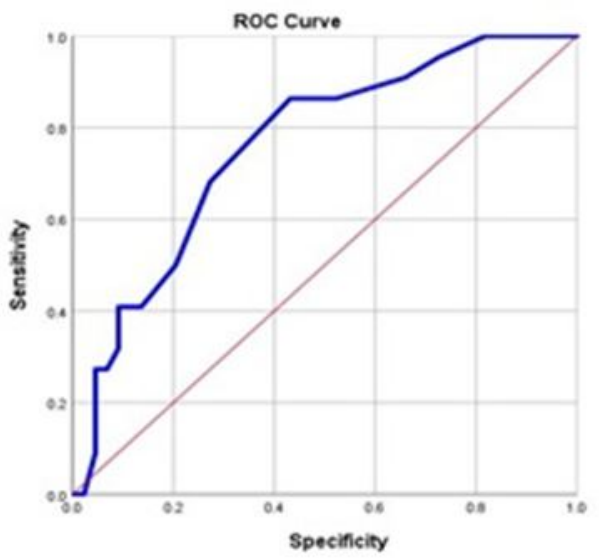

The LT RA RI had an AUC 0.753 (95\% CI: 0.631-0.876, p 0.001) figure 5, RT RA RI [AUC 0.760 (95\% CI: 0.641$0.880, \mathrm{p} 0.001)]$ Splenic artery RI [AUC 0.754 (95\% CI: 0.634-0.873, p 0.001)]. It can be concluded that LT RA RI performed almost better than the RT RA RI for the detection of bleeding esophageal varices.

Figure (7): ROC curve of the splenic

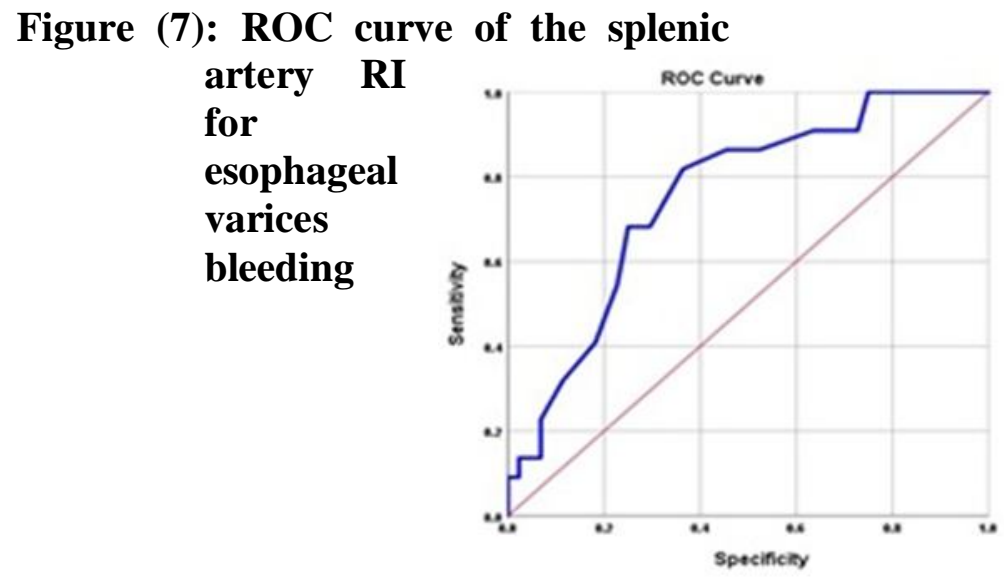

ROC curve analysis of splenic artery RI revealed that a cut off value of $(0.725)$ has a sensitivity of $68.2 \%$, and a specificity of $70.5 \%$ for prediction of esophageal varices bleeding. (Figure 7). 


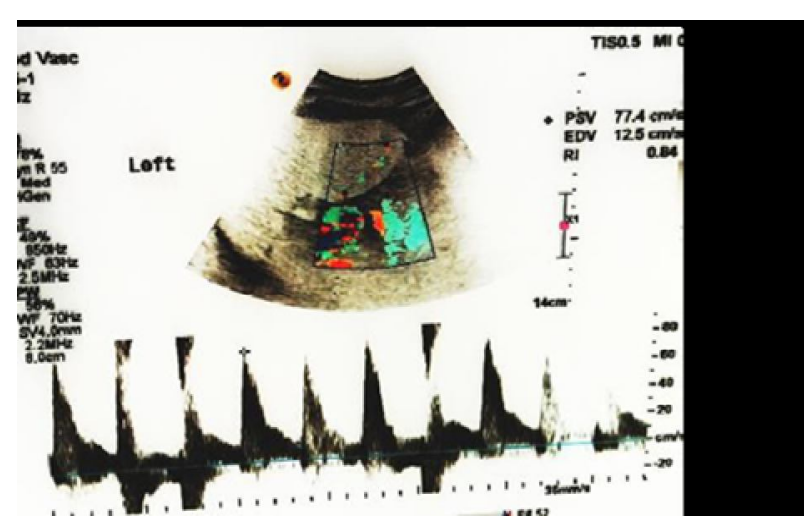

A

Figure (8): 64-year-old man with cirrhosis. The patient had no history of hematemesis. Doppler US shows RARI (A)

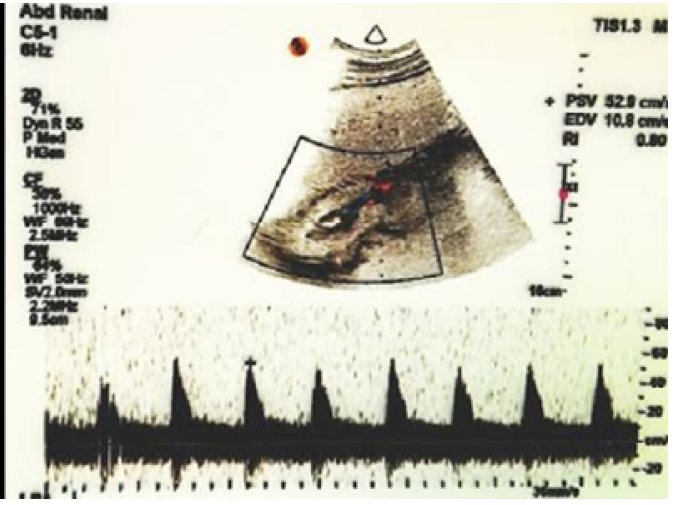

A

Figure (9): 55-year-old female with cirrhosis. The patient had a history of hematemesis with esophageal bleeding. Doppler
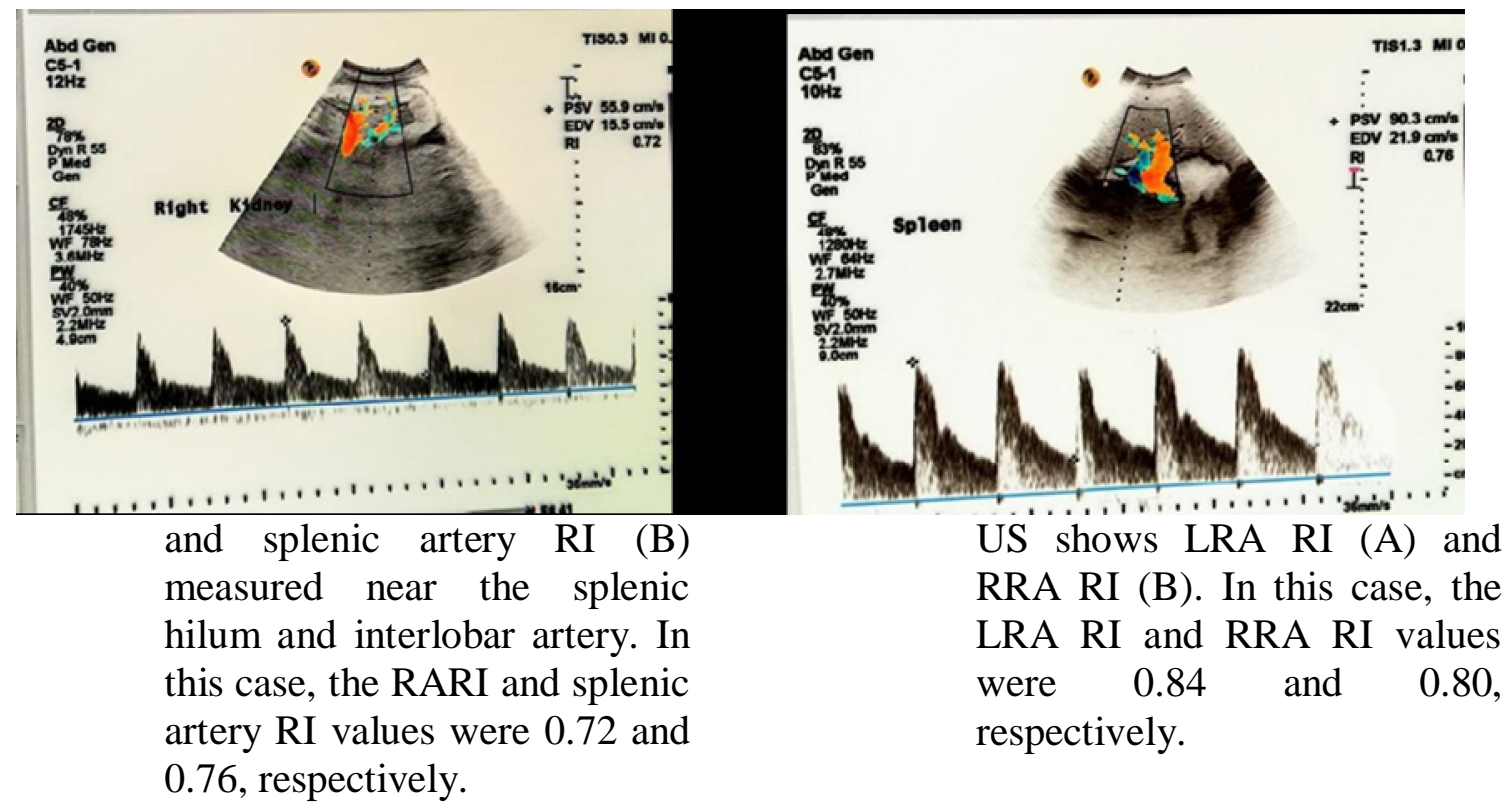

\section{DISCUSSION}

Esophageal varices (EV) are the most relevant portosystemic collaterals (PSCs) and have the greatest clinical impact where variceal hemorrhage is associated with higher morbidity, mortality and hospital costs than other causes of upper gastrointestinal tract bleeding. Endoscopic screening of all cirrhotic patients for the presence of varices at the time of

diagnosis is recommended by consensusbased guidelines (Emam et al., 2009).

However, a generalized screening program of periodical upper endoscopy in cirrhotic patients may lead to high cost and low compliance, as the procedure is invasive and may be poorly accepted by the patients if repeatedly required (Franchis et al., 2008). Moreover, sedation of cirrhotic patients to perform upper endoscopy may be hazardous, and 
diagnostic upper endoscopy may contribute to bacterial infections due to disruption of the normal barriers (Yosry et al., 2009). For these reasons, the selection of patients who may be at risk of having $\mathrm{EV}$, especially those at risk for rupture, would be highly beneficial and costeffective (Franchis et al., 2008). The need for noninvasive diagnosis for detection of EV and assessing the effect of therapy will benefit in high-risk situations (Berzigotti et al., 2013).

Many studies have attempted to identify characteristics that noninvasively predict the presence of varices. These studies have shown that clinical, biochemical and ultrasonographic parameters alone or together have good predictive power for noninvasively assessing the presence of $\mathrm{O} . \mathrm{V}$ (Sarangapani et al., 2010).

(Shastri et al., 2014) used Portal Vein Doppler as a tool for non-invasive prediction of esophageal varices in cirrhosis show portal vein velocity (PVV) had the highest sensitivity of $84 \%$ (95\% CI $66.45 \%-94.10 \%$ ) for detecting the presence of EV. Portal vein diameter (PVD) and hepatic congestion index (HCI) had the highest specificity of 55\% (95\% CI 0.31-0.77). So Portal vein Doppler as a tool for predicting EV has several limitations, and EGD still remains the gold standard for the diagnosis and management of $\mathrm{EV}$.

In our study, we used renal artery and splenic artery resistive index for prediction of esophageal varices and their bleeding in 66 liver cirrhosis patients, and their diagnostic ability for esophageal varices was assessed using multiple statistical approaches.
Some single parameter was found to offer sufficient predictive value for esophageal varices. However, a combination of multiple parameters (RRA RI, LRA RI) significantly improves the predictive accuracy for the presence of large esophageal varices. Based on a stepwise multivariate logistic regression analysis, a predictive model was proposed (2.91 RRA RI+3.25 LRA RI - 3.79) with an optimal cut-off value of 0.397 has a sensitivity of $95.7 \%$, and a specificity of $50 \%$ for prediction of esophageal varices.

The present study showed that the resistive index of the renal artery has significant importance in predicting the presence and bleeding risk of esophageal varices in cirrhotic patients.

Our study revealed that the resistive index of the renal artery was an important non-invasive predictor of esophageal varices, with a cut off value of 0.715 having $80.4 \%$, sensitivity and $25 \%$ specificity.

Also, resistive index of the renal artery was an important non-invasive predictor of esophageal varices bleeding risk, with a cut off value of 0.725 having $81.8 \%$, sensitivity and $50 \%$ specificity. The splenic artery resistive index revealed that a sensitivity of $69.6 \%$, and a specificity of $90.1 \%$ for prediction of esophageal varices in a cut off value of 0.715 , and a sensitivity of $68.2 \%$, and a specificity of $70.5 \%$ for prediction of esophageal varices bleeding in a cut off value of 0.725 .

This was in line with (Byun and Kim, 2007) who found significant role of resistive index of the renal artery in predicting esophageal varices bleeding with the mean values of variables were 


\section{SHABAN SALAH AL-AZHARY et al.,}

higher in bleeders than in non-bleeders. The correlation coefficient between splenic artery RI and RARI was 0.78 ( $p<0.01)$. RIR had a sensitivity of $88.3 \%$, a specificity of $75.0 \%$, and an accuracy of $81.8 \%$ at a cutoff value of 0.70 for the prediction of bleeding.

Also, our finding was concordant with (Thayumanavan et al., 2012) who found high RARI correlated directly with the degree of the varices, and a higher RARI is associated with increased UGI bleed, about $76 \%(75.60 \%)$ having RARI of $\geq 0.67$ had grade 2 and 3 varices. About $66.7 \%$ having RARI $<0.67$ had grade 1 or no varices $(\mathrm{P}<0.05)$. Sixty percent of patients with RARI $\geq 0.67$ had an upper gastrointestinal (UGI) bleeding episode. Twenty percent of patients with RARI $<0.67$ had UGI bleed.

On the other hand; our results were not matching with the study of (Chakrabarti et al., 2016) that indicated that splenic artery RI showed no significance. This discordance may be attributed to child score of patients in their study (ChildPugh class A) vs (Child-Pugh class A, B and $C$ ) in our study, the variable that was associated with high-risk esophageal varices.

\section{CONCLUSION}

A high RA RI appeared to be associated with esophageal varices and its bleeding in patients with liver cirrhosis. We suggest that RA RI is a useful predictor of varices and its bleeding, and that it should be used clinically to decide the patient who receive prophylactic therapy, and for follow up.

\section{REFERENCES}

1. Augustin, Salvador, Gonz?lez $A$ and Genescà J (2010): Acute esophageal variceal bleeding: Current strategies and new perspectives. World journal of hepatology, 2: 261-74.

2. Baik, K S (2010): Haemodynamic evaluation by Doppler ultrasonography in patients with portal hypertension: a review. Liver International, 30: 1403-13.

3. Berzigotti A, Seijo S, Reverter $\mathbf{E}$ and Bosch $\mathbf{J}$ (2013): Assessing portal hypertension in liver diseases, Expert Review of Gastroenterology \& Hepatology, 7:2, 141-155.

4. Byun, $\mathbf{N}$ J and Kim D H (2007): The Value of Renal Artery Resistive Indices: Association with Esophageal Variceal Bleeding in Patients with Alcoholic Cirrhosis. Journal of the Korean Radiological Society, 56: 355-60.

5. Chakrabarti R, Sen D and Khanna V (2016): Is non-invasive diagnosis of esophageal varices in patients with compensated hepatic cirrhosis possible by duplex Doppler ultrasonography? Indian Journal of Gastroenterology, 35: 60-66.

6. Dagradi A E, Stephen J S and Owens L K (1966): Bleeding esophagogastric varices: An endoscopic study of 50 cases. Archives of Surgery, 92: 944-47.

7. Emam E, Ramadan A, Badway M, Atia H, Abo Warda M H and Gawish H H (2009): Prediction of oesophageal varices in patients with compensated cirrhosis: A novel scoring system. Arab Journal of Gastroenterology, 10: 129-34.

8. Franchis D, Roberto, Eisen G M, Laine L, Inaki F-U, Juan M H, Brown R D, Fisher L, Vargas $H$ E, Vargo $J$ and Thompson $J$ (2008): Esophageal capsule endoscopy for screening and surveillance of esophageal varices in patients with portal hypertension. Hepatology, 47: 1595-603.

9. Jain P, Tripathi B K, Gupta B, Rathore B and Jalan D (2015): Evaluation of Aspartate Aminotransferase-to- Platelet Ratio Index as a Non-Invasive Marker for Liver Cirrhosis. Journal of Clinical and Diagnostic Research, 9(11): 22-4. 
10. Kim G, Cho Y Z, Soon K B, Kim M Y, Hong W K and Sang O K (2015): The accuracy of ultrasonography for the evaluation of portal hypertension in patients with cirrhosis: a systematic review. Korean Journal of Radiology, 16: 314-24.

11. Kraja, Bledar, Mone I, Akshija I, Koçollari A, Prifti S and Burazeri G (2017): Predictors of esophageal varices and first variceal bleeding in liver cirrhosis patients. World journal of gastroenterology, 23: 4806.

12. Mishra K P (2016): New Delhi, India: Jaypee.Variceal Upper Gastrointestinal Bleeding, in Patta Radhakrishna, Pavan Addala (EDS.), Textbook of Surgical Gastroenterology, volume 2 ( $\mathrm{p}$ 1277).

13. Primignani, Massimo, Carpinelli L, Preatoni P, Battaglia G, Carta A, Prada A, Cestari R, Angeli P, Gatta A and Rossi A (2000): Natural history of portal hypertensive gastropathy in patients with liver cirrhosis. Gastroenterology, 119: 181-87.

14. Sarangapani A, Shanmugam C, Kalyanasundaram M, Rangachari B, Thangavelu P and Subbarayan J K (2010): Noninvasive prediction of large esophageal varices in chronic liver disease patients. Saudi journal of gastroenterology: official journal of the Saudi Gastroenterology Association, 16: 3842.

15. Sarin, S K, Lahoti D, Saxena S P, Murthy N $S$ and Makwana U K (1992): Prevalence, classification and natural history of gastric varices: a long-term follow-up study in 568 portal hypertension patients. Hepatology, 16: 1343-49.
16. Shastri $M$, Kulkarni $S$, Patell $R$ and Jasdanwala S (2014): Portal vein Doppler: a tool for non-invasive prediction of esophageal varices in cirrhosis. Journal of clinical and diagnostic research: JCDR,8: MC12.

17. Thakeb F, Zakaria S, Hunter $M$ and Zakaria S (1988): A study of the oesophagus by endoscopy and radiology after sclerotherapy. Gastrointestinal Endoscopy: An Egyptian View. Egypt: El-Sona El-Mohamadia, 51.

18. Thayumanavan L, Vasudevan S, Rathinam R, Mariappan K, Pudusery J, Hercule $H$ and Theophilus P (2012): 31 A study on usefulness of renal artery resistive index as a noninvasive predictor of varices and bleed in cirrhosis with portal hypertension. Journal of Clinical and Experimental Hepatology, 2: S20.

19. Uppalapati, Suraj and Lokesh S (2018): Correlation of portal vein diameter with the presence of oesophageal varices in chronic liver disease: a prospective study. International Journal of Advances in Medicine, 5(4):859864.

20. Viazzi F, Giovanna L, Derchi L E and Pontremoli R (2014): Ultrasound Doppler renal resistive index: a useful tool for the management of the hypertensive patient. Journal of hypertension, 32: 149-53.

21. Yosry, Ayman, Fouad R, Abd Elbary M, Hamdy S, Mahmoud $M$ and Khairy $M$ (2009): Non-Invasive Prediction of Varices in Egyptian Cirrhotic Patients. Med. J. Cairo Univ, 77: 343-49. 


\section{در اسة مؤشرات المقاومة للشريان الطحالى و الثريان الكلوى

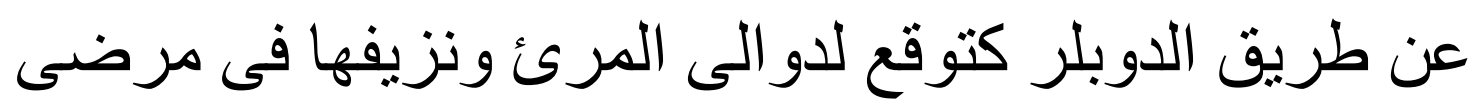 مصربين مصابين بالتليف الكبدى لألى}

شعبان صلاح الأزهري *ـ سامى زكى* ـ عبدالله حسين أحمد**. محمود حجاج عبدالفضيل

قسم الأمراض المتوطنة ـ كلية الطب - جامعة الأزهر * ـ قسم الأثشعة ـ كليه الطب (بنات) - جامعة الأزهر **

خلفية البحث : يعد دو الى المرئ من المضاعفات الرئيسية لتليف الكبد ، وقد تؤدى إلى نزيف بالجهاز

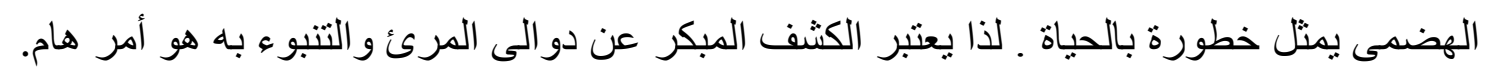
الهلف من البحث: نهدف فى هذة الدر اسة إلى تقييم مؤشر مقاومة الثريان الكلوى و الثريان الطحالى في

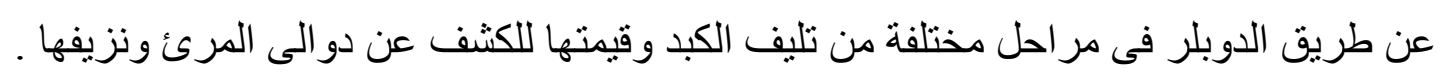
المرضي و طرق البحث: شملت هذة الدراسـة 77 مريضـا بتشخيص مؤكد لتليف كبد موز عـة على ثلاث مجمو عات :

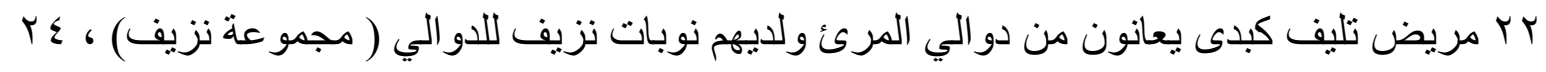

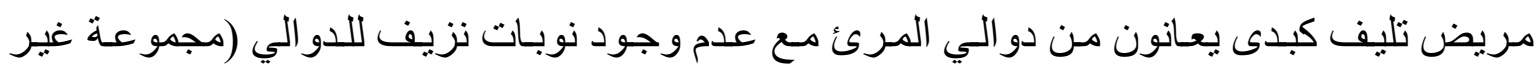

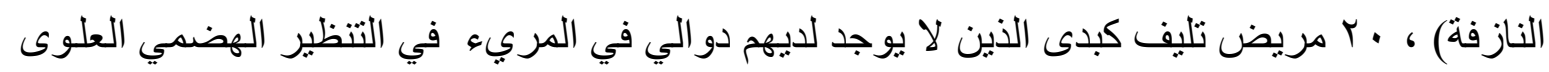

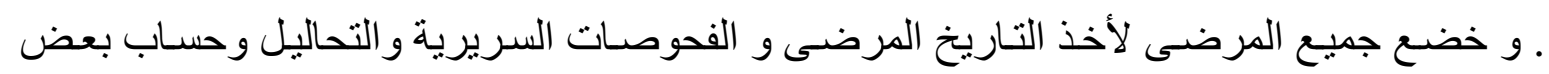

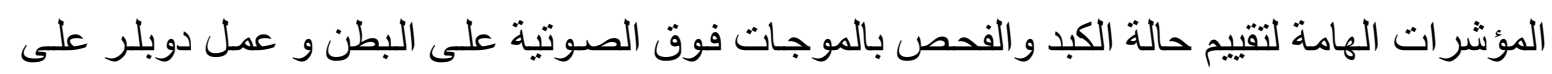

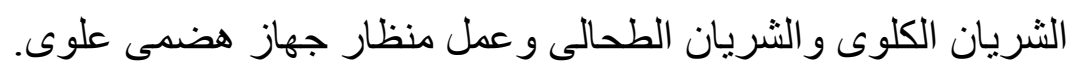

النتائج: مؤشر المقاومة للشريان الكلوى خدم فى التتبو بوجود دو الى المرئ وكذلك فى نزيف دولى الكى

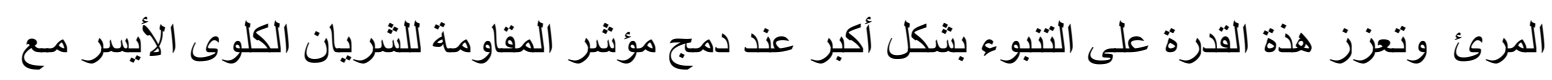

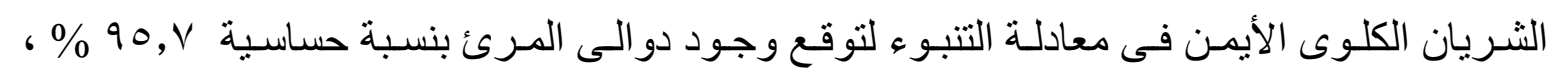

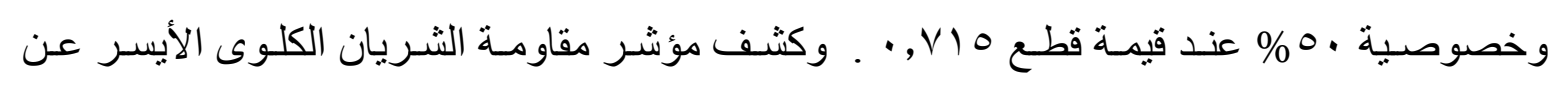

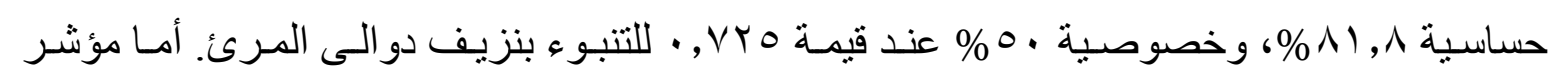

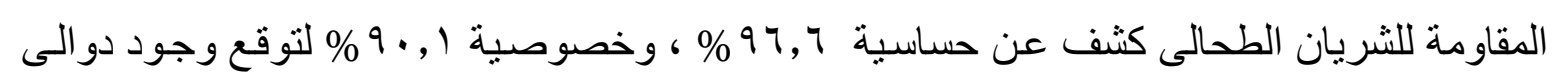

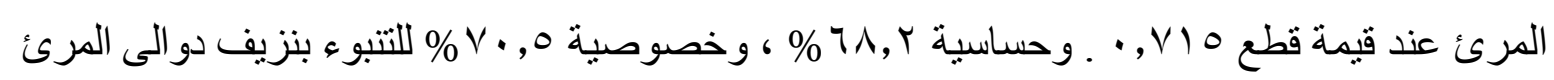

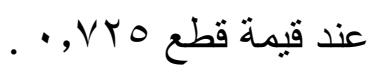


الاستنتاج: مؤشر المقاومة للثريان الكلوى يمكن ان يتنبأ بوجود دو الى المرئ. وكذلك يعد مؤشر

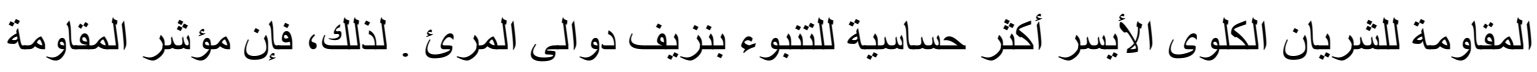

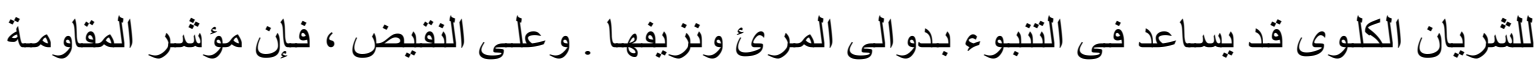

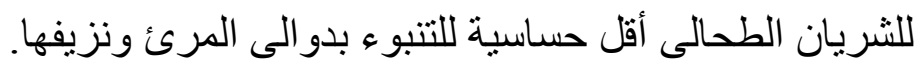

